\title{
Model Desain Thinking Pada Perancangan Aplikasi Mobile Learning
}

\author{
John Reimon Batmetan, Alfandy Parera,Klaudia Maki, Jezkri Ondang \\ Teknik Informatika, Universitas Negeri Manado, Tondano 95618 \\ john.reimon@gmail.com, alfandyparera@unima.ac.id, klaudiamaki@unima.ac.id, \\ Jezkriondang@unima.ac.id
}

\begin{abstract}
Abstrack
Tekologi yang sudah semakin maju dijaman sekarang ini terlebih unyuk telepon seluler. Pada saat ini hamper setiap orang memiliki telepon seluler. Teknologi telepon seluler juga berkembang dari masa ke masa. Hingga sampai saat ini telepon seluer sudah bisa digunakan untuk banyak hal termasuk sebagai media pembelajaran. Media pembelajaran yang biasa digunakan melalui telepon seluler biasa disebut Mobile Learning. Mobile Leraning ini digunakan untuk menjangkau atau lebih memudahkan proses pembelajaran bagi para pelajar dan juga para pengajaran. Namun dalam kenyataan banyak aplikasi Mobile Leraning yang sedikit digunakan dikarenakan tampilan dan fitur yang ada didalam aplikasi Mobile Learning yang tidak menarik bagi pengguna. Untuk itu kami merancang aplikasi mobile leraning dengan menggunakan metode desain Thinking. Metode ini adalah metode kreatif karena dengan menggunakan metode ini para pengembang bisa berkreasi dengan ide-ide mereka, tapi juga mereka bisa mengetahui kebutuhan dari pengguna.
\end{abstract}

Kata Kunci : Mobile Learning, Metode DesainThinking

\section{PENDAHULUAN}

[1]Perkembangan teknologi saaat ini sudah semakin berkembang, Menurut Kementrian Komunikasi dan Informatika pada Mei 2014, pengguna internet di Indonesia mencapai angka 82 juta orang. pada tahun 2016 mencapai 132,7 juta orang dan pada tahun 2017 mencapai 143,26 juta orang. Pengguna internet di Indonesia yang paling banyak saat ini digunakan oleh mahasiswa yang mencapai $89,7 \%$. Teknologi perangkat mobile saat ini sudah sedemikian cepat perkembangannya sehingga pengguna perangkat mobile mencapai 63,1 juta orang atau $(47,6 \%)$ dari penduduk Indonesia. [1]Perangkat mobile seperti telepon.smarthpon dan tablet Pc dapat digunakan dalam mengakses media pembelajaran mobile learning yang merupakan pengembangan dari E-learning. Perangkat mobile dapat dimanfaatkan dalam berbagai bidang kehidupan, salah satu contohnya adalah pada bidang pendidikan dimana Jenis konten Internet yang diakses di pendidikan mencapai 124,4 juta orang atau setara dengan $93,8 \%$.

[2] aplikasi yang dapat mengakses materi ,arahan yang berkaitan dengan pembelajaran tanpa dibatasi oleh ruang dan waktu, dimanapun dan kapanpun mereka berada dengan menggunakan perangkat bergerak seperti telepon genggam disebut dengan mobile learning.[3]Dibandingkan dengan computer smarthphone lebih dikenal oleh masyarakat oleh karena itu smarthphone menjadi pilihan terbaik dalam pengaplikasian mobile 
learning. Oleh karena itu maka kami akan membuat desain aplikasi mobile learning dengan menggunakan metode desain thinking agar dapat membantu pengguna dalam mengakses pembelajaran dengan tampilan yang mudah dimengerti.

\section{LITERATUR REVIEW}

\section{M-Learning}

[4]Menurut Clark Quinn (2006) Mobile Learning sebagai : The intersection of mobile computing and e-learning: accessible resources wherever you are, strong search capabilities, rich interaction, powerful support for effective learning, and performance-based assessment. Elearning independent of location in time or space. [1] Menurut Crescente dan Lee, 2010 Perangkat mobile seperti telepon.smarthpon dan tablet Pc dapat digunakan dalam mengakses media pembelajaran mobile learning. [6]M-learning memungkinkan adanya lebih banyak kesempatan untuk berinteraksi dengan secara tidak langsung diantara pengguna(mahasiswa) dengan pengajar (dosen).

m-learning juga merupakan media pembelajaran dimana pengguna (mahasiswa) dapat mengakses materi pembelajaran dimanapun dan kapanpun sehingga dapat meningkatnkan perhatian pengguna pada materi pembelajaran dan mendorong motivasi belajar.[3]tipe e-learning yang mendistribusikan konten pembelajran dan materi pendukung yang menggunakan alat komunikasi wireless disebut dengan M-learning.

\section{Android}

[5]menurut meier (2009), sebuah software stack bersifat open source yang mencakup sistem operasi , middelware, dan key Aplications beserta sekumpulan application programming interface untuk merancang sebuah aplikasi mobile dengan menggunakan bahasa pemrograman java disebut Androit. [7]Menurut (Darcey \& Conder, 2010). Android adalah sebuah platform open source yang didesain untuk perangkatperangkat bergerak (mobile). [3]Android menyediakan platform terbuka bagi para pengembang untuk menciptakan aplikasi mereka sendiri untuk digunakan oleh bermacam peranti bergerak.

Android merupakan suatu sistem operasi untuk telepon seluler (handphone) yang berbasis Linux. Android adalah software untuk perangkat mobile yang mencakup sistem operasi, middleware dan aplikasi kunci.

3. Model Desain Thinking.

[8]Menurut (Glinski, 2012).Design Thinking adalah sebuah pola pemikiran dari kaca mata desainer yang dalam memecahkan masalahnya selalu dengan pendekatan human oriented. [9] Menurut Dr Edward de Bono Kemampuan berpikir desain akan lebih mendasarkan pada pola-pola baru penciptaan karena dalam prosesnya lebih menitikberatkan kepada aktivitas persepsi, posibilitas, dan praktek. Dalam perkembangannya metode design thinking ini dirumuskan menjadi 5 (lima) langkah oleh IDEO yakni Penemuan Inspirasi, Interpretasi, Penggalian Ide, Eksperimen, Evaluasi dan Evolusi.

\section{METODELOGI PENELITIAN}

Penelitian ini menggunakan metodelogi penelitian Desain thinking yang merupakan cara berpikir kreatif dan praktis dalam memecahkan masalah atau pekerjaan.

Desain Thinking memiliki 5 tahapan yaitu :

\section{Emphatize (empati)}

Thapan dimana kita mengamati apa yang dilakuka user dan cara mereka berinteraksi 
dengan lingkungannya, terlibat secara langsung dapat mmbantu dalam mengungkapkan cara berpikir dan nilai-nilai yang mereka pegang, setelah mengamati dan melibatkan diri dengan user,penting juga untuk merasakan langsung pengalaman dari user.

\section{Define(menentukan)}

Pada tahap ini kita menentukan permasalahan yang berfokus pada user yang spesifik dan berdasarkan insight dan kebutuhan - kebutuhan user.

\section{Ideation}

Mengeluarkan pendapat atau ide-ide yang dapat menjadi solusi terhadap permasalahan.

4. Prototipe

Mengaplikasikan ide-ide yang sudah dikumpulkan ke dalam bentuk fisik,dapat berupa catatan yang ditempel di tembok ,objek, atau bahkan storyboard.

\section{Test (uji coba)}

Tahapan test adalah peluang untuk memperbaiki solusi kalian dan membuatnya lebih baik lagi.

Tahap pengumpulan data kami menggunakan metode desain sprint dimana desain sprint adalah metode membangun konsep produk dalam 6 tahapan yaitu : understand, define, diverge, decide, prototype, dan validate.

\section{HASIL DAN PEMBAHASAN \\ 1. UNDERSTAND}

\subsection{Memahami permasalahan}

Berdasarkan diskusi kami menemukan beberapa masalah utama yang ditemukan pada proses pembelajaran yaitu tampilan aplikasi mobile learning yang sangat sulit untuk dimngerti , sehingga saat proses pembagian materi masih menggunakan flash dapat memperlambat proses belajar-mengajar karna harus di copy satu persatu, pemberian dan pengumpulan tugas yang masih dilakukan secara manual atau di print dapat memakan bnyak biaya oleh karena itu kami ingin menyelesaikan masalah diatas dengan membuat sebuah aplikasi mobile learning yang dapat bermanfaat.

\subsection{Tinjaun}

Menurut tinjauan kami sudah banyak aplikasih mobile learning tapi masih sedikit yang menggunakan aplikasih tersebut karena terdapat beberapa masalah atau kendala yang ditemukan.

\section{3 wawancara}

kami melakukan wawancara kepada stackholder kami yaitu dosen dan mahasiswa untuk mengetahui kendala dan masalah yang sering ditemukan dalam Pemakain aplikasih mobile learning sehingga dapat menjadi acuan bagi kami untuk membuat aplikasi yang dapat bermanfaat. Dan kami menemukan masalah-masalah yang sering dialami yaitu :

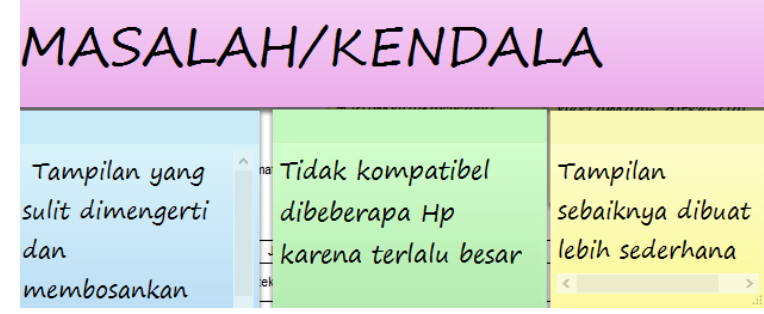

Gambar 1 : masalah-masalah

\section{4 kunjungan lapangan}

setelah melakukan kunjungan lapangan kami dapat melihat proses pembelajaran yang dilakukan dimana saat tidak ada dosen beberapa mahasiswa hanya berdiam diri dan tidak belajar karena tidak adanya materi yang diberikan atau tugas yang diberikan saat dosen beraada di luar daerah dan juga ada beberapa mahasiswa yang dating ke kampus hanya untuk mengambil materi sehingga dapat menghambat proses pembelajaran.

1.5 Stakeholder

Stakeholder kami yaitu :

- Dosen /Pengajar

- Mahasiswa/Pelajar 


\subsection{Kesimpulan}

Kesimpulannya yaitu dibutuhkan aplikasi mobile learing yang dapat membantu proses pembelejaran menjadi lebih cepat dan dapat dilaksanakan dan dapat diakses dimanapun dan kapanpun dengan tampilan yang sederhana.

\section{DEFINE}

\subsection{Pengalaman Pengguna}

Berdasarkan pengalaman user saat menggunakan aplikasih mobie learning kita dapat mengetahui bagaimana perjalanan pengguna atau user saat menggunkan aplikasi mobile learing dan kita dapat menemukan masalah-masalah yang dihadapai atau kendala saat menggunakan aplikasi mobile leraning. Sehingga dari situ kita bisa belajar untuk memebuat aplikasih yang lebih bermanfaat lagi.

\subsection{Prinsip Desain}

Berdasarkan pengalaman pengguna kita dapat menemukan beberapa kebutuhan dan desain yang diiginkan, dan melalui wawancara kami dapat menemukan bebrapa kebutuhan pengguna yang telah kami rangkum dalam sebuah sticky note di bawah ini :

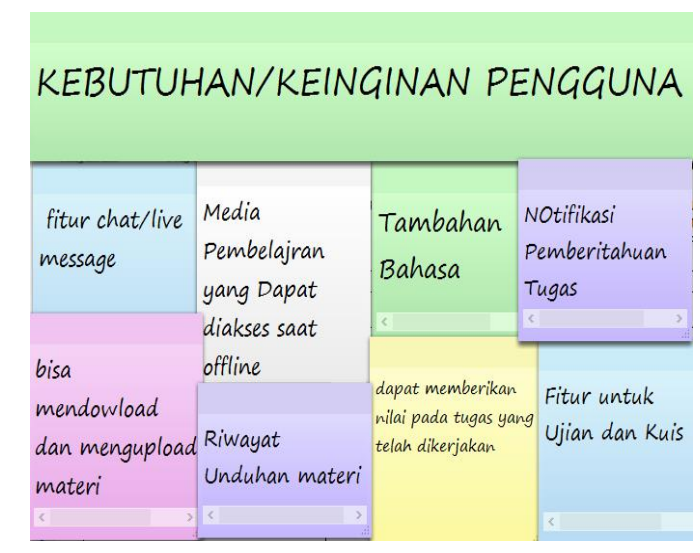

\subsection{The First Tweet ( Peluncuran)}

"Mau belajar cepat? Mau mendownload dan belajar materi dimanapun? Mau memasukkan tugas dengan cepat? Download aplikasi Mobile Learning (Bekeng Pande), yang bisa membantu kita belajar dimanapun dan kapanpun."

\section{DIVERGE}

Pada tahap ini tim kami membuat desain kasar storyboard aplikasi mobile learning yang akan kami buat sesuai dengan kebutuhan dan masalah yang telah kami temui di atas, tim kami membuat dua rancangan desain yang nantinya akan di voting oleh stakeholder kami, Rancangannnya seperti di bawah ini :

1.

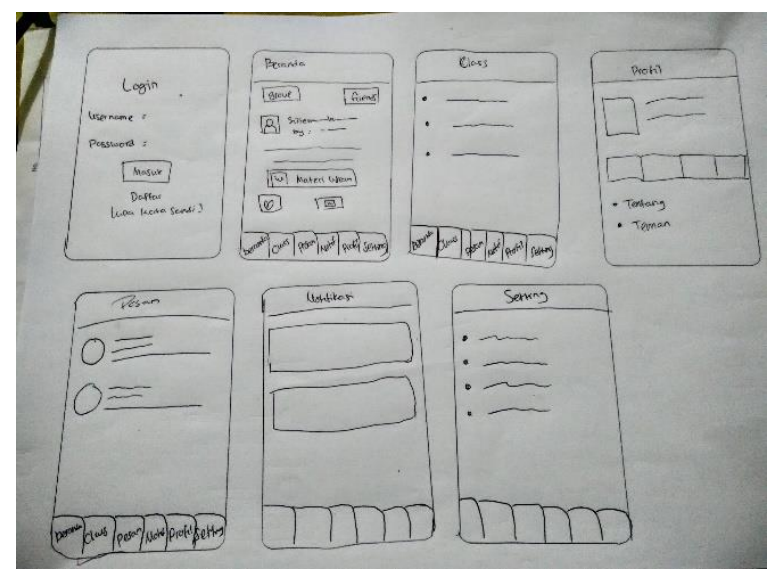

2.

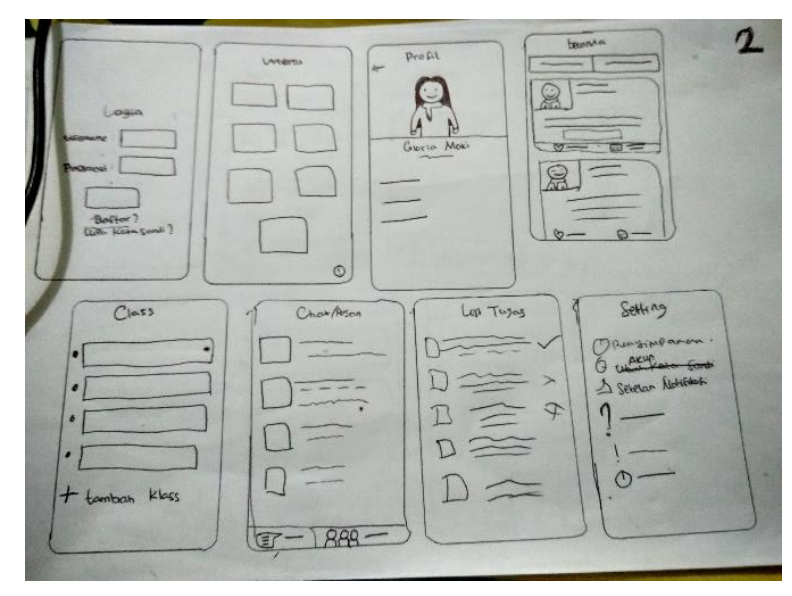

\section{DECIDE}

\subsection{Voting}

Setela membuat sketsa, kami melakukan voting dengan cara menempelkan kedua sketsa tersebut 
di papan tulis dan mendorong beberapa orang untuk melakukan voting terhadapat sketsa yang mereka inginkan.
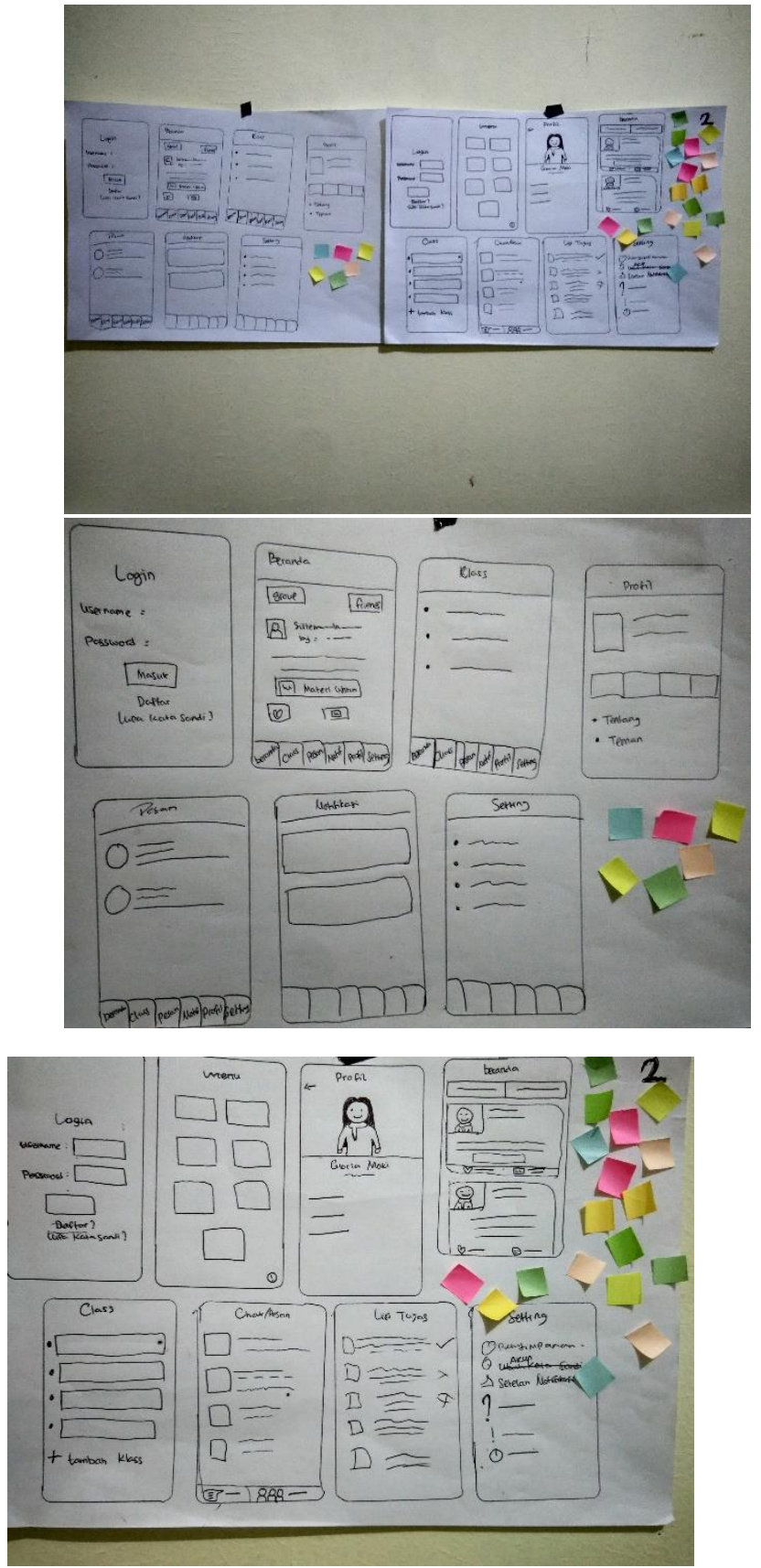

\subsection{Review Tim}

Setelah mealkukan voting tim kami berdiskusi tentang pilihan voting terbanyak yang akan kami jadikan acuan untuk desain aplikasi mobile learning kami. Dan kami menemukan bahwa pilihan kedua memiliki voting terbanyak yaitu 18 Orang dan pilihan 1 mendapat 6 .

\subsection{Thinking hats}

Pada tahap ini kami berdiskusi tentang keputusan yang telah diambil dan saling mencurahkan pendapat untuk tahapan desain brikutnya pada desain tampilan kedua yang telah dipilih oleh user.

\section{Prototype}

- Tampilan Login

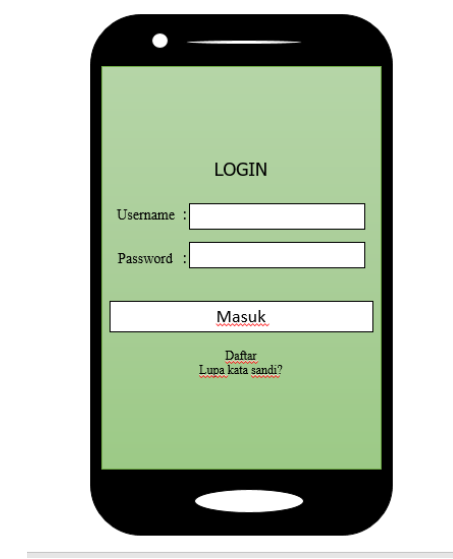

- Tampilan Menu Awal

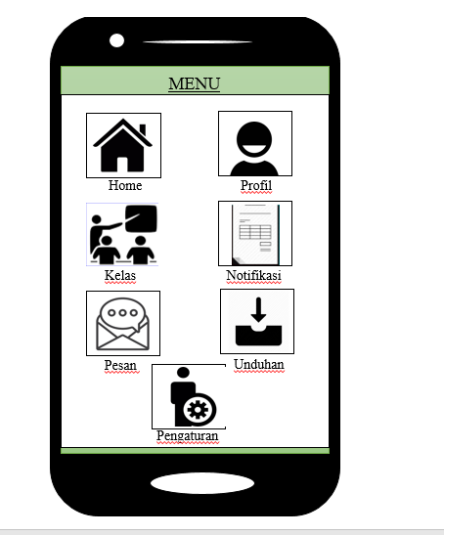

- Tampilan Home 


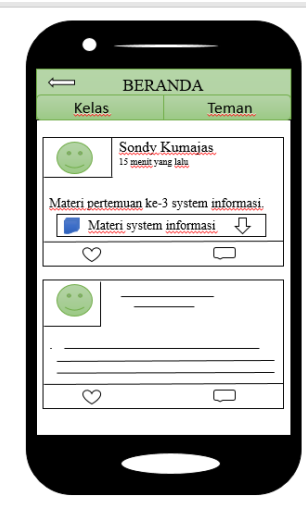

- Tampilan unduhan

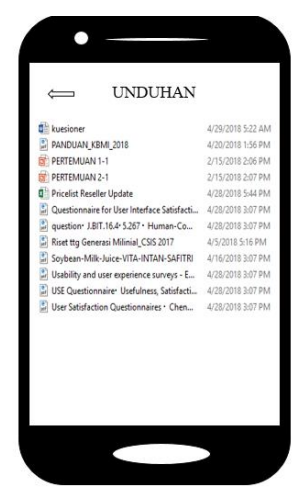

- Tampilan profil

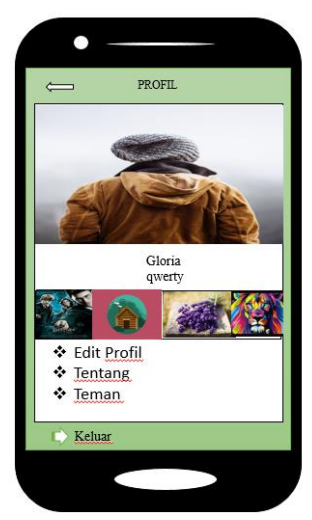

- Tampilan Kelas

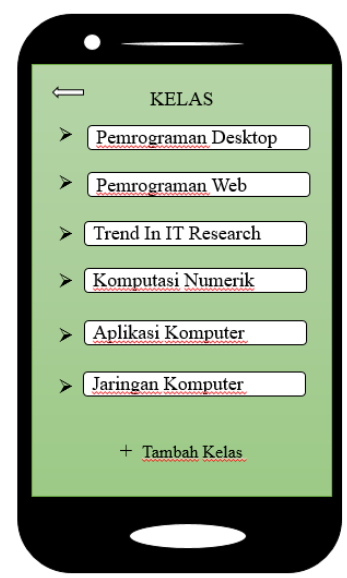

- Tampilan Pesan

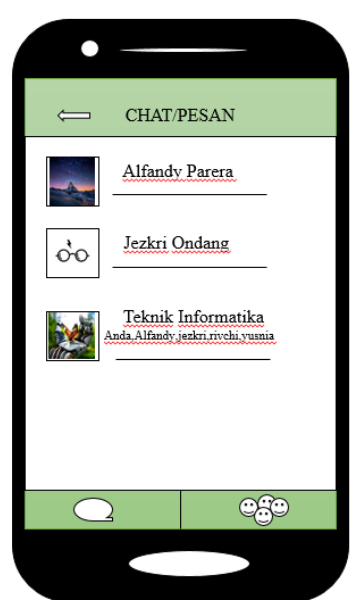

- Tampilan Notiikasi

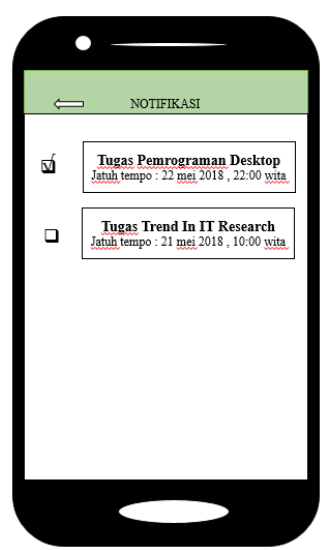


- Tampilan Pengaturan

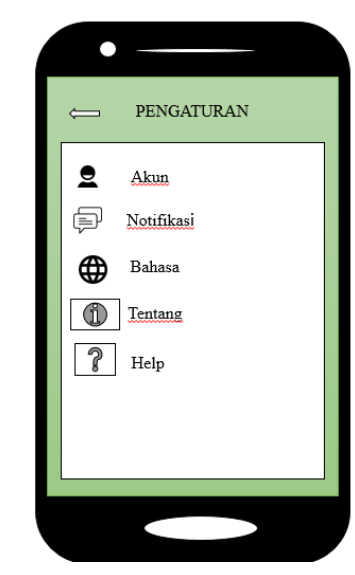

\section{VALIDATE}

Pada tahap ini kami melakukan tes atau menunjukan tampila desain yang telah dibuat dan juga meberikan kesempatan bagi user untuk mencoba menggunkan simulasi aplikasi yang kami buat di ppt.

\section{KESIMPULAN}

Kesimpulan yang dapat diambil dari perancangan aplikasih mobile learning dengan menggunakan metode desain thinking ini adalah dengan adanya aplikasi mobile learning ini kita tidak harus melakukan pengajaran secara konvensional yang harus tatap muka, dengan adanya mobile Learning akses belajar mengajar dapat dilakukan dimana pun, dan kapapun, serta dengan adanya mobile Learning ini proses pengajaran dalam suatu perkuliahan dapat lebih efektif karena ada tidaknya dosen pada saat perkuliahan berlangsung, materi ajar tetap dapat disampaikan kepada mahasiswa dengan fitur mengupload materi dan juga untuk mengunduh materi yang diajarkan, fitur tugas untuk mengumpulkan tugas yang telah diberikan, serta fitur pesan yang digunakan untuk saling komunikasi antar kelompok maupun komunikasi langsung dengan dosen, sehingga waktu satu semester untuk perkuliahan tersebut dapat digunakan semaksimal mungkin dengan adanya mobile Learning.

\section{DAFTAR PUSTAKA :}

[1] I. Soleh, "APLIKASI M-LEARNING BERBASIS HTML5 MENGGUNAKAN," no. 1, pp. 61-66, 2015.

[2] S. ko. cecep furqon, St , aris sunandang, "Aplikasi Mobile Learning (M-Learning) Untuk Mata Kuliah Pengantar Teknologi Informasi Berbasis Java 2 Micro Edition (J2me)," wawasan Ilm. Publ. AMIK garut, vol. 7, pp. 1-9, 2015.

[3] A. W. Purnamasari, A. A. K. C. Wiranatha, and N. M. I. M. Mandenni, "Aplikasi MLearning pada Platform Android," Merpati, vol. 2, no. 2, p. 219, 2014.

[4] M. I. Aripurnamayana, "Rancangan Dan Pembuatan Mobile Learning Berbasis Android ( Studi Kasus: Pembelajaran Sejarah Di Smp )," J. Inform. Univ. Gunadarma, vol. 7, pp. 19, 2012.

[5] H. Rizal, S. Adhy, and P. W. Wirawan, "PERANCANGAN DAN PEMBUATAN MOBILE LEARNING INTERAKTIF BERBASIS ANDROID DENGAN METODE PERSONAL EXTREME PROGRAMMING," vol. 2, no. 3, pp. 1-10, 2013.

[6] A. P. Putera et al., "Aplikasi M-Learning Berbasis Windows Phone Untuk Jurusan Teknologi Informasi," Merpati, vol. 3, no. 2, pp. 87-95, 2015.

[7] I. M. Wijayanto2, Arif Wibisono3, "Mobilelearning (m-learning)," 2014.

[8] S. Arrohman, "Konferensi Nasional 'Inovasi dan Technopreneurship' IPB International Convention Center, Bogor, 18-19 Februari 2013," Res. Bus. DIPONEGORO Univ. Dedic. Indones. YOUNG TECHNOPRENEUR TO BUILT UP Bright NATION, no. Mkk 2308, pp. 18-19, 2013.

[9] C. Paper, "Kajian Design Thinking: Proses Metakognisi dalam Pelaksanaan Proyek Desain 
Produk ( Studi Kasus Proyek Studio Desain Produk ber ....," no. May, 2014.

[10] J. R. Batmetan Suyoto, J. D. C. L. Suares, "An Empirical Investigation on Customer Behavior to Adopt Mobile Commerce among the $\mathrm{Y}$ Generation in Indonesia", Sriwijaya International Conference On Engineering, Science \& Technology [SICEST 2016], 2016

[11] J.R. Batmetan, "Algoritma Ant Colony Optimization (ACO) untuk Pemilihan Jalur Tercepat Evakuasi Bencana Gunung Lokon Sulawesi Utara", Jurnal Teknologi InformasiAITI, 2016, vol.13, no.2, pp 31-48

[12] L. Madeso, D. R. Kabo, J. R. Batmetan, " Rancang Bangun Sistem Pakar Penentuan Status Gizi Pada Balita Menggunakan Metode Forward Chainning", E-Jurnal UNSRIT, vol.2

[13] J. R. Batmetan, V. R. Palilingan, " Higher Education Students' Behaviour to Adopt Mobile Learning", IOP Conference Series: Materials Science and Engineering, 2018, vol. 306, Issue 1, pp. 012110 (2018)
[14] V. R. Palilingan, J. R. Batmetan, " Incident Management in Academic Information System using ITIL Framework", IOP Conference Series: Materials Science and Engineering, 2018, vol. 306, Issue 1, pp. 012110 (2018)

[15] J. R. Batmetan, A. J. Santoso, Pranowo, " A Multiple-Objective Ant Colony Algorithm for Optimizing Disaster Relief Logistics", Advanced Science Letters, 2017, vol.23, no.3, pp. 2344-2347

[16] M. L. Tompodung, F. Supit, J. R. Batmetan, " Rancang Bangun Aplikasi Sensus Penduduk Berbasis Android", Buletin Sariputra, 2017, vol.7, pp. 57-61

[17] J. R. Batmetan, " Optimasi Strategi Smart Environment Dalam Mitigasi Bencana Menggunakan Multi-Objective Aco (Mo-Aco) Algorithm", Pasca Sarjana Magister Teknik Informatika Universitas Atma Jaya Yogyakarta, 2016 